\title{
Bacteria Inactivation during the Drying of Struvite Fertilizers Produced from Stored Urine
}

\author{
Heather N. Bischel, ${ }^{\dagger}$ Simon Schindelholz, ${ }^{\dagger, \|}$ Manfred Schoger, ${ }^{\dagger, \|}$ Loïc Decrey, ${ }^{\dagger}$ Christopher A. Buckley, \\ Kai M. Udert, ${ }^{\S}$ and Tamar Kohn*,† \\ ${ }^{\dagger}$ Laboratory of Environmental Chemistry, School of Architecture, Civil and Environmental Engineering (ENAC), École \\ Polytechnique Fédérale de Lausanne (EPFL), CH-1015 Lausanne, Switzerland \\ ${ }^{\ddagger}$ Pollution Research Group, Faculty of Engineering, University of KwaZulu-Natal, Durban 4041, South Africa \\ ${ }^{\S}$ Eawag: Swiss Federal Institute of Aquatic Science and Technology, 8600 Dübendorf, Switzerland
}

\section{Supporting Information}

ABSTRACT: Human urine can be processed into market-attractive fertilizers like struvite; however, concerns regarding the microbial safety of such products remain. The present study evaluated the inactivation of in situ heterotrophs, total bacteria as observed by flow cytometry, and inoculated Enterococcus spp. and Salmonella typhimurium during the drying of struvite under controlled temperature (from 5 to $35{ }^{\circ} \mathrm{C}$ ) and relative humidity (approximately 40 and $80 \%$ ) as well as dynamic field conditions. Bacteria accumulated in the struvite cake during struvite filtration. Despite the use of sublethal temperatures, all bacteria types were subsequently inactivated to some degree during struvite drying, and the inactivation typically increased with increasing drying temperature for a given relative humidity. Heterotrophic bacteria inactivation mirrored the trend in total bacteria during struvite drying. A linear relationship was observed between inactivation and sample moisture content. However, bacteria survivor curves were typically nonlinear when struvite was dried at low relative humidity, indicating bacterial persistence. Weibull model survivor curve fits indicated that a shift in the mechanism of inactivation may occur with changing humidity. For increased efficiency of bacterial inactivation during the production of struvite, initial heating under moist conditions is recommended followed by desiccation.

\section{INTRODUCTION}

Struvite $\left(\mathrm{MgNH}_{4} \mathrm{PO}_{4} \cdot 6 \mathrm{H}_{2} \mathrm{O}\right)$ has long been known in wastewater treatment as a scale deposit that causes maintenance problems and reduces treatment efficiency. ${ }^{1}$ More recently, centralized wastewater treatment plants are recognizing the potential of struvite as a phosphorus-rich fertilizer, simultaneously removing scale throughout the treatment works while offsetting some treatment costs from its sale. ${ }^{2}$ Recycling of $\mathrm{P}$ in this way is important since modern agriculture depends on the nutrient, but it is mined from finite global reserves. ${ }^{3}$ Struvite's high $\mathrm{P}$ content, low solubility in water and convenience as a solid, dense and odorless fertilizer contribute to its market potential as a slow-release fertilizer in agriculture. ${ }^{4,5}$ While struvite production from wastewater or dry sanitation systems has not yet proven economically self-sustaining, ${ }^{2,6}$ revenue can be generated alongside meeting waste discharge requirements by producing increasingly valuable fertilizers, especially as the market price of $\mathrm{P}$ continues to rise.

Many researchers have focused on struvite production from human urine, for example in Nepal, ${ }^{5,6}$ Vietnam, $^{7}$ and Durban, South Africa. ${ }^{8,9}$ Human urine is the main source of $\mathrm{P}$ in wastewater. The $\mathrm{P}$ in human urine, if collected, could offset more than $10 \%$ of the total global P demand. ${ }^{10}$ Urine can be collected and stored separately from solids through urinediverting toilets, from which point it can be used directly as a fertilizer following a minimum of 6 months storage at $20{ }^{\circ} \mathrm{C}$. ${ }^{11}$ Alternatively, urine can be processed into more manageable, market-attractive products (e.g., with less foul odor) like struvite. The high $\mathrm{pH}$ and high $\mathrm{P}$ levels in stored urine require only the addition of a magnesium source for spontaneous precipitation of struvite. $^{12}$

Struvite precipitation has received much attention due to its process simplicity, but the hygienic quality of the end-product generated in field settings has not been thoroughly evaluated. Source-separated urine collected in Durban, for example, contains a diversity of pathogens and high concentrations of locally prescribed pharmaceuticals. ${ }^{13}$ When struvite is precipitated from urine, pharmaceuticals largely remain in the effluent of struvite reactors, yielding low concentrations in the struvite

\section{Received: July 15, 2016}

Revised: October 26, 2016

Accepted: November 8, 2016

Published: November 8, 2016 
product. $^{14,15}$ Viruses are retained in residual urine in the struvite after filtration, and human virus surrogates $\Phi$ X174 were shown to inactivate in struvite under mild temperature drying conditions due to reduction in the product moisture content. ${ }^{16}$ Larger sized helminth ova accumulate in struvite during filtration and require elevated temperatures and reduced moisture contents in the struvite to achieve inactivation. ${ }^{16}$ The fate of bacteria in urine during struvite recovery and processing has not been previously described.

Here, we evaluate the fate of in situ bacteria in urine as well as surrogates for human pathogens (Salmonella typhimurium and Enterococcus spp.) during the production of struvite from laboratory reactors and a pilot-scale reactor operated in Durban. Test conditions $\left(5-35{ }^{\circ} \mathrm{C}, 40\right.$ and $80 \%$ relative humidity) were selected to reflect struvite production in the field without additional energy input to create harsher drying conditions and corresponded to conditions previously used to study virus and helminth inactivation. ${ }^{16}$ Results from isothermal drying conditions conducted in the laboratory were also compared to drying struvite under fluctuating relative humidity and temperature in the field. These studies together were used to develop recommendations for enhanced struvite production procedures and to increase the safety of using urine-derived fertilizers.

\section{MATERIALS AND METHODS}

Inactivation of bacteria in struvite dried under a range of controlled and uncontrolled (ambient) conditions was quantified for heterotrophic bacteria, the Gram-negative Salmonella typhimurium, and Gram-positive Enterococcus spp. via plate counts as well as for total bacteria via flow cytometry (FC). This range of analytical techniques was selected to provide information on different end-product quality targets and insight into inactivation processes. The experimental approach also included the production of struvite from urine collected from different sources, and drying experiments were conducted in the laboratory and the field.

Urine Sources and Characterization. Source-separated urine was obtained from the men's urine storage tank at the Swiss Federal Institute of Aquatic Science and Technology (Eawag, Switzerland) to produce struvite at a laboratory-scale and evaluate the inactivation of spiked Enterococcus spp. and $S$. typhimurium as well as in situ heterotrophic bacteria under controlled struvite drying conditions. Additionally, sourceseparated urine was obtained from mixed-gender urine storage tanks maintained by eThekwini Water and Sanitation (EWS) and from household storage tanks and a community ablution block in eThekwini Municipality (the municipality in the Durban region) to evaluate variability in the inactivation of in situ heterotrophs in urine or struvite produced at a laboratoryscale. Struvite was also produced from pilot-scale reactors at EWS using urine obtained from the EWS mixed-gender urine storage tanks; these bags of struvite were dried under ambient (uncontrolled) conditions. A subset of urine samples were characterized for ammonium, phosphate, conductivity, chemical oxygen demand and $\mathrm{pH}$ as described in the Supporting Information (Table S1).

Struvite Production. For laboratory-scale experiments, each struvite cake was produced in sterile reactors as previously described from $1 \mathrm{~L}$ of urine by adding $1.5 \mathrm{~g} \mathrm{MgCl}_{2} \cdot 6 \mathrm{H}_{2} \mathrm{O}$ (Acros Organics, Geel, Belgium), gently stirring for $10 \mathrm{~min}$, and filtering through a nylon filter (pore diameter $\cong 18-240 \mu \mathrm{m}$ ) cut to fit the filtration unit ( $45 \mathrm{~mm}$ diameter) using a manual pump. ${ }^{16}$ For pilot-scale experiments, four struvite batches were produced from reactors built and maintained by EWS. ${ }^{9}$ Urine storage tanks were mixed with a peristaltic pump prior to being pumped into the reactor. For a single struvite batch, up to 320 $\mathrm{L}$ of urine was dosed with industrial grade magnesium sulfate heptahydrate $\left(\mathrm{MgSO}_{4} \cdot 7 \mathrm{H}_{2} \mathrm{O}\right.$, Strathmore Mine, Malelane, South Africa), filtered sequentially through cotton filter bags ( $\sim 100 \mu \mathrm{m}$ pore size), and air-dried following previously described procedures. ${ }^{9}$

Controlled Struvite Drying. Struvite cakes were dried by evaporation under a combination of various controlled temperature and relative humidity conditions. The temperatures were $5{ }^{\circ} \mathrm{C}, 20^{\circ} \mathrm{C}$, or $35^{\circ} \mathrm{C}$, and the low and high relative humidity levels were approximately $40 \%$ or $80 \%$, respectively. Relative humidity was maintained using $150 \mathrm{~mm} \times 150 \mathrm{~mm}$ desiccators (Nalgene, Thermo Fisher Scientific, Waltham, MA) containing $50 \mathrm{~mL} \mathrm{LiCl}$ or $\mathrm{NaBr}$ saturated salt solutions $(88 \mathrm{~g}$ / $\mathrm{mL}$ and $95 \mathrm{~g} / \mathrm{mL}$, respectively) and a water-soaked tissue for low and high relative humidity conditions, respectively. The relative humidity stabilized after about $6 \mathrm{~h}$. The temperature and relative humidity were observed using an Irox Piccolo indoor thermometer/hygrometer (OS Technology AG/SA, Gümligen/Bern, Switzerland) placed inside the desiccator for each experiment.

Controlled drying experiments were conducted in duplicate, such that two struvite cakes were dried in the same desiccator with the same temperature and humidity conditions. The effective moisture content of struvite cakes $\left(\theta_{\mathrm{g}}\right)$ is reported as

$$
\theta_{g}(\%)=\frac{M_{\mathrm{ww}}-M_{\mathrm{dw}}}{M_{\mathrm{dw}}}
$$

where $M_{\mathrm{ww}}$ and $M_{\mathrm{dw}}$ are the wet weight (ww) and dry weight (dw) masses of struvite, respectively. The $d w$ was measured as the stable weight of struvite when dried at reference laboratory conditions $\left(20 \pm 3{ }^{\circ} \mathrm{C}\right.$ and $\left.30 \pm 5 \% \mathrm{RH}\right)$.

Ambient Struvite Drying. A total of nine struvite cakes were dried outside at EWS facilities in Durban, South Africa. Four of these struvite cakes were produced from the pilot-scale reactors with cloth filters and dried under cover to prevent exposure to direct sunlight, four were produced at laboratory-scale with nylon filters and dried under cover, and one was produced at a laboratory-scale and dried under natural sunlight. The temperature and relative humidity were monitored with a HOBO Pro v2 external temperature/relative humidity data logger (Onset Computer Corporation, Bourne, MA) during the drying of pilot-scale struvite cakes and with a TFD 128 temperature/ relative humidity data logger (Conrad Electronic, Berlin, Germany) for the laboratory-scale struvite cakes.

Bacteria Enumeration by Plate Count. Urine and struvite samples were enumerated for heterotrophic bacteria, Salmonella typhimurium, and Enterococcus spp. Details regarding the source and enumeration of the organisms are described in the Supporting Information. Concentrations are reported as colony forming units ( $c f u$ ) per $\mathrm{mL}$ urine or cfu per $\mathrm{g} d w$ struvite, unless otherwise stated.

Bacteria Enumeration by Flow Cytometry. Flow cytometry with appropriate cell staining procedures provides a cultureindependent method of evaluating the inactivation of all bacteria, including viable and culturable bacteria, viable but nonculturable bacteria and nonviable bacteria. An FC viability assay was conducted on a subset of struvite suspensions to provide insight into the mechanisms of bacterial inactivation 


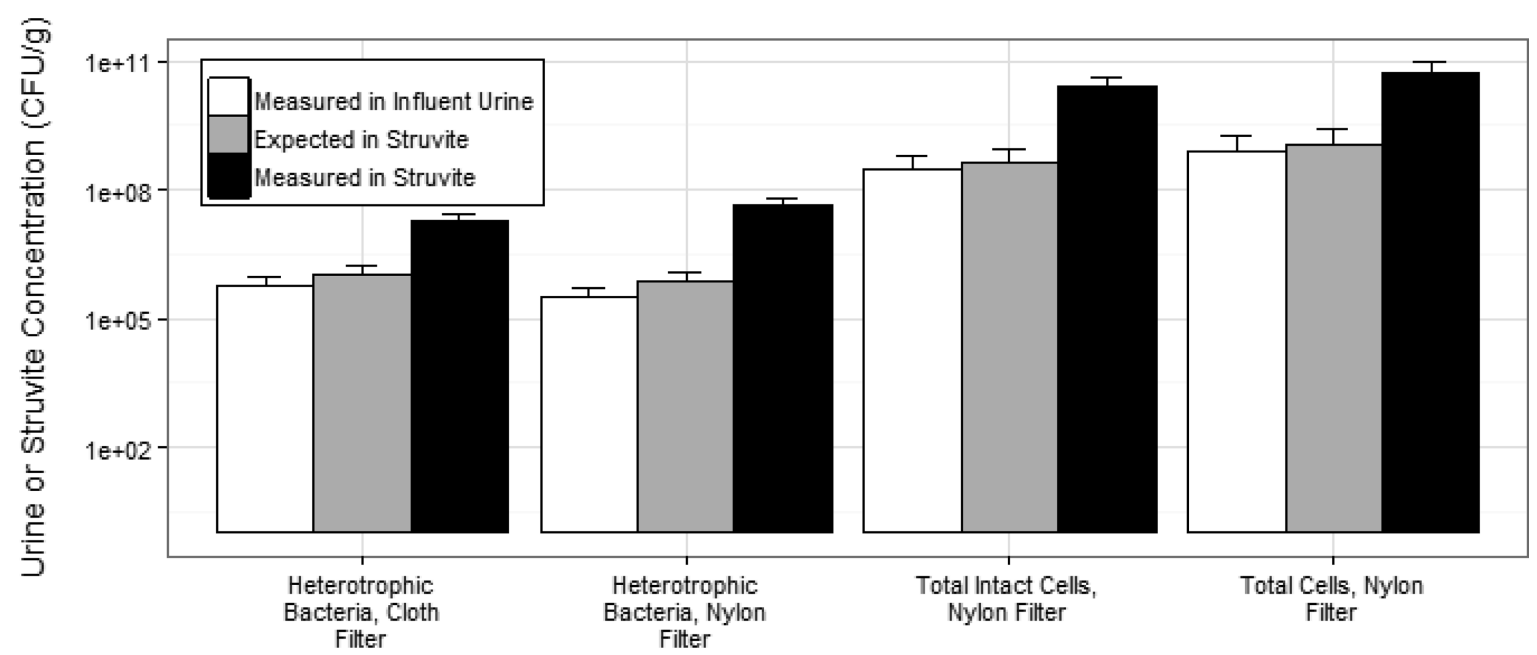

Figure 1. Accumulation of bacteria during struvite formation. The concentration expected in struvite (CFU/g dw) was calculated from the urine influent concentration $(\mathrm{CFU} / \mathrm{g})$ and the initial sample moisture content in the struvite sample. Error bars here are $95 \%$ confidence intervals.

and to evaluate the robustness of the simple plating procedures to reflect overall trends in bacterial inactivation. Total cell counts (total bacteria), total intact cell counts (live bacteria), and membrane-compromised cell counts (dead bacteria) were measured in urine and dissolved struvite samples using a CyFlow CL flow cytometer (Sysmex Partec GmbH, Görlitz, Germany), applying a live/dead staining procedure (e.g., Figure S1-S3). The SYBR Green and propidium iodide (PI) staining procedure was adapted from Berney et al., ${ }^{17}$ as described in the Supporting Information.

Data Analysis. The Weibull model in the form presented by Mafart et al. ${ }^{18}$ was selected to model survivor curves and was applied to log-transformed data using Microsoft Excel and the add-on tool Ginafit. ${ }^{19}$ This model allows for a dispersion of resistance toward inactivation described by the Weibull distribution. $^{20}$ The concentration of surviving organisms (C, $\mathrm{CFU} / \mathrm{g}$ struvite or counts/g struvite) is modeled as a function of time $(t)$ by the equation:

$$
\log _{10}(C)=\log _{10}\left(C_{0}\right)-\left(\frac{t}{\delta}\right)^{p}
$$

where $C_{0}$ is the initial concentration, $\delta$ is the time for first decimal (90\%) reduction, and $p$ is a shape parameter. The Weibull model has the advantage of describing nonlinear survival curves that have a shoulder $(p>1)$ or tail $(p<1)$ without substantial additional empirical complexity. Because the $\delta$ and $\mathrm{p}$ parameters in the Weibull model are autocorrelated, the model is sometimes applied with a fixed $p$ value, usually the average $p$ from several survivor curves evaluated at different temperatures. The special case of $p=1$ simplifies to the classic log-linear inactivation equation, and $\delta$ becomes $D$, the time for decimal reduction that is independent of elapsed experimental time. Weibull model parameters were determined without a fixed $\mathrm{p}$ for each experimental condition using the average bacterial concentrations in two side-by-side struvite cakes. In addition, an average $\mathrm{p}$ was calculated for struvite dried in field conditions $(p=0.38)$, and the model was rerun with this fixed value on those curves.

Nondetect data were excluded from the fits, except for the first data point below the detection limit when available, which was set to the limit of quantitation (see Supporting Information) as a conservative estimate of the extent of inactivation. HPC and total bacteria were never observed below the detection limit. The slope of the linear regression was considered significantly different from zero if $p<0.05$ by ANOVA.

\section{RESULTS AND DISCUSSION}

Viable Bacteria Content in Stored Urine Is Highly Variable. Heterotrophic plate count (HPC) bacteria were detected in all urine samples tested, ranging from $4 \times 10^{2}$ to 3 $\times 10^{8} \mathrm{CFU} / \mathrm{mL}$ in urine collected from different sources and at different times. The range of in situ heterotrophic bacteria concentrations reflects the variability of contamination of the urine from fecal matter or other sources as well as variability in the storage times and temperatures of the urine before sampled. Flow cytometry results confirm the presence of a large number of live bacteria in stored urine (Figure S1). The approximate residence time of urine in the sampled tank was between 37 and 47 days. ${ }^{21}$ As expected, HPC detected only a small fraction of the total bacteria present in the urine. In side-by-side measurements, concentrations of heterotrophic bacteria in urine ranged from $4 \times 10^{2}$ to $2 \times 10^{4} \mathrm{CFU} / \mathrm{ml}(n=8)$, while total intact cell counts (live bacteria) ranged from $1 \times 10^{7}$ to 7 $\times 10^{8}$ counts $/ \mathrm{mL}$.

While Gram-negative bacteria inactivate rapidly in urine, ${ }^{22}$ our data indicate that some in situ HPC bacteria are expected to persist and remain detectable. Bacterial communities in source-separated urine from two locations in the United States were dominated by Clostridiales and Lactobacillales after 80 days of storage. ${ }^{23}$ Spore forming Gram-positive bacteria such as Clostridium perfringens are known to resist inactivation in stored urine. $^{24}$ Therefore, source-separated urine should not be considered sterile, even after long-term storage. A reduction in the live bacteria content during urine processing to fertilizer is thus desirable.

Bacteria Accumulate in Struvite during Filtration. An accumulation of heterotrophic bacteria and total bacteria in struvite was observed for struvite produced from either the nylon or the cloth filters used for laboratory and pilot-scale production, respectively (Figure 1). An expected concentration of bacteria in the struvite was calculated based on the residual urine present in the struvite, determined from the effective moisture content of struvite samples taken immediately after 

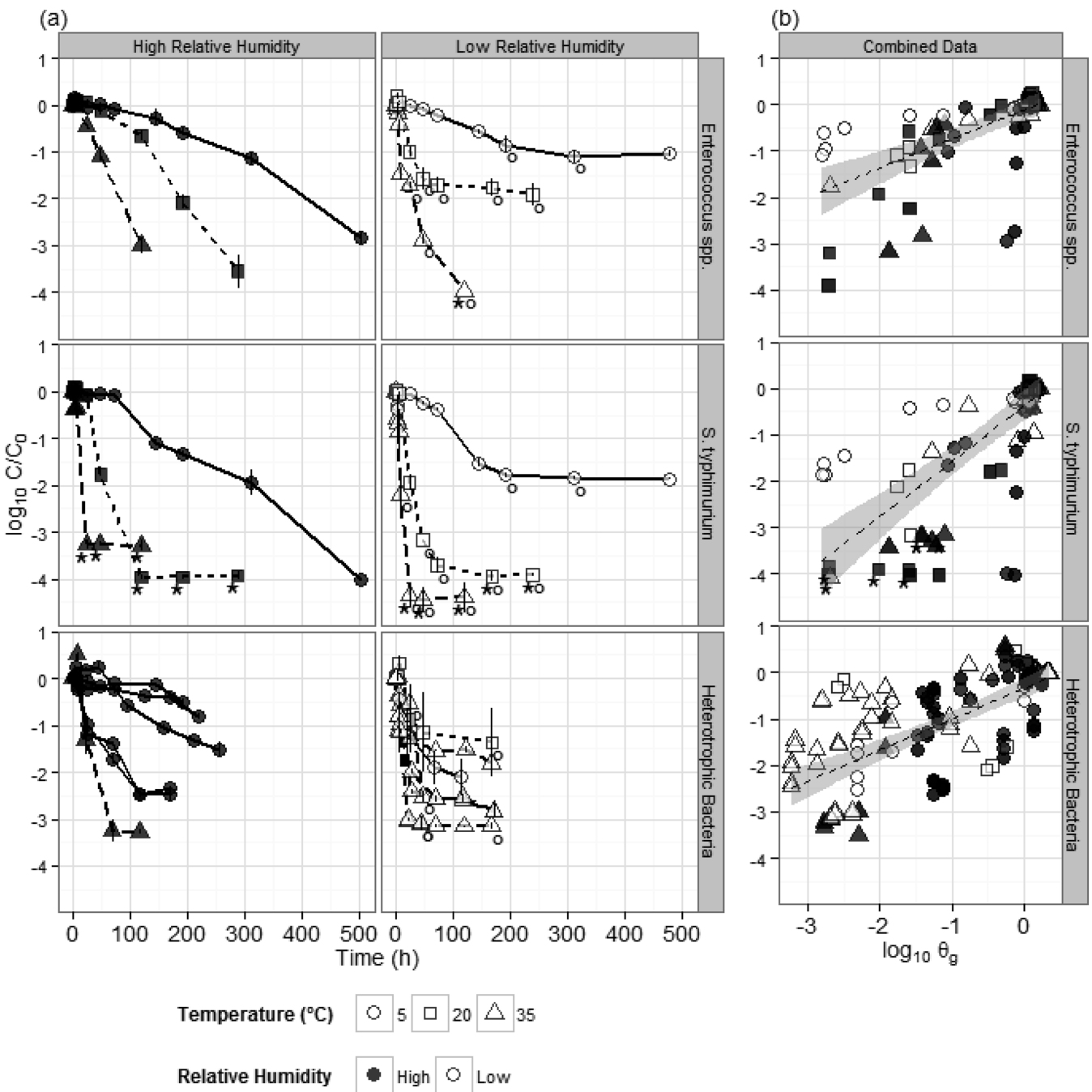

Figure 2. Inactivation of bacteria (Enterococcus spp., S. typhimurium, and heterotrophic bacteria) during the drying of struvite with controlled temperature and relative humidity (a). Linear regression when plotting the relative concentration of bacteria $\left(\log _{10} C / C_{0}\right)$ in struvite against sample moisture content $\left(\log _{10} \theta_{\mathrm{g}}\right)$, shown with regression standard error in gray $(\mathrm{b})$. Heterotrophic bacteria inactivation was evaluated in repeat controlled drying experiments for struvite produced from different urine sources, with emphasis on the extreme conditions (low humidity/35 ${ }^{\circ} \mathrm{C}$ and high humidity $/ 5{ }^{\circ} \mathrm{C}$ ). Concentrations of bacteria are reported as $\mathrm{CFU} / \mathrm{g}$ struvite (dry weight); the moisture content was calculated on a dry weight basis. Results were marked with "o” if at least one of the samples had no measurable residual moisture; results were marked with "*” if at least one of the concentrations was below the limit of detection.

production, and the measured concentration of bacteria in the source urine. The measured concentrations of bacteria in the struvite were greater than these expected concentrations by up to 2 orders of magnitude, suggesting additional mechanisms of bacterial retention besides the residual moisture. This was true for HPC (ratios of measured/expected concentrations ranged from 31 to $250, n=16$ ), total intact cells detected by FC (ratios from 30 to $340, n=4$ ), and total cells (ratios from 20 to 350,n $=4)$ in struvite produced using nylon filters. Struvite produced using cloth filter bags at the pilot-scale also retained heterotrophic bacteria, with the ratios of measured to expected concentration ranging from 10 to $61(n=4)$. The nylon and cloth filters used for drying have similar pore sizes, so the reduced accumulation of bacteria in the field setting relative to the laboratory may be due to the reactor configuration and field struvite production protocol, in which elevated pressure is manually applied to increase urine flow rates through the filter.

The observed accumulation of bacteria in struvite from urine indicates that at least two-log reduction in live bacteria concentration following struvite production is required to achieve a net benefit in microbial quality as compared to that required for urine (on an equivalent mass basis). The inactivation of bacteria during struvite drying is subsequently evaluated, first in controlled conditions followed by field settings.

Inactivation of in Situ Heterotrophic Bacteria during Controlled Drying of Struvite. The inactivation curves for HPC bacteria during the drying of struvite under controlled temperature and relative humidity are displayed in Figure 2a (lowest panels). In some struvite batches, up to approximately 3-log inactivation was achieved in less than $100 \mathrm{~h}$ drying. However, the extent of inactivation ranged widely for different drying conditions and often did not reach this level, even after almost $200 \mathrm{~h}$ drying. Struvite was also produced from urine that originated from different sources, either eThekwini (South Africa) or Eawag (Switzerland), to evaluate the variability of in situ heterotrophic bacteria inactivation under repeat controlled drying experiments with emphasis on the extreme conditions 
Table 1. Weibull Model Parameters for Inactivation of Heterotrophic Plate Count (HPC) Bacteria Sourced from Eawag, Switzerland or Durban, South Africa as well as Enterococcus spp., S. typhimurium, Total Intact Cells (TIC) and HPC Measured alongside TIC in Struvite Dried at Controlled Temperature and Relative Humidity

\begin{tabular}{|c|c|c|c|c|c|c|c|}
\hline drying condition & bacteria & $\operatorname{RMSE}^{a}$ & $R^{2}$ & $\delta(\mathrm{h})^{b}$ & $p^{c}$ & $\log _{10}\left(C_{0}\right)$ & $t_{4 \mathrm{D}}(\mathrm{d})^{d}$ \\
\hline \multirow[t]{9}{*}{$35^{\circ} \mathrm{C} /$ low RH } & HPC (Eawag) & 0.91 & 0.76 & $8 \pm 26$ & $0.33 \pm 0.30$ & $6.6 \pm 0.9$ & 23 \\
\hline & & $0.50^{e}$ & 0.94 & $2 \pm 4$ & $0.41 \pm 0.19$ & $7.4 \pm 0.5$ & 3 \\
\hline & HPC (eThekwini) & 0.11 & 0.98 & $10 \pm 7$ & $0.20 \pm 0.04$ & $6.5 \pm 0.1$ & 415 \\
\hline & & 0.43 & 0.92 & $2 \pm 4$ & $0.24 \pm 0.10$ & $7.9 \pm 0.4$ & 24 \\
\hline & & 0.23 & 0.97 & $2 \pm 3$ & $0.25 \pm 0.06$ & $7.7 \pm 0.2$ & 25 \\
\hline & Enterococcus spp. & 0.41 & 0.94 & $6 \pm 5$ & $0.50 \pm 0.12$ & $6.0 \pm 0.4$ & 4 \\
\hline & S. typhimurium & 0.43 & 0.96 & $4 \pm 2$ & $0.85 \pm 0.21$ & $6.3 \pm 0.4$ & 1 \\
\hline & TIC & 0.23 & 0.95 & $18 \pm 6$ & $0.84 \pm 0.25$ & $10.6 \pm 0.2$ & 4 \\
\hline & HPC (alongside TIC) & 0.27 & 0.94 & $33 \pm 5$ & $2.4 \pm 0.9$ & $6.1 \pm 0.1$ & 2 \\
\hline \multirow[t]{3}{*}{$35^{\circ} \mathrm{C} /$ high $\mathrm{RH}$} & HPC (Eawag) & $0.87^{e}$ & 0.88 & $13 \pm 20$ & $0.64 \pm 0.41$ & $7.9 \pm 0.8$ & 5 \\
\hline & Enterococcus spp. & 0.03 & 1.00 & $44 \pm 1$ & $1.11 \pm 0.03$ & $6.01 \pm 0.02$ & 6 \\
\hline & S. typhimurium & 0.19 & 0.99 & $14 \pm 3$ & $2.0 \pm 0.8$ & $4.8 \pm 0.1$ & 1 \\
\hline \multirow[t]{4}{*}{$20{ }^{\circ} \mathrm{C} /$ low $\mathrm{RH}$} & Enterococcus spp. & 0.41 & 0.84 & $20 \pm 28$ & $0.35 \pm 0.15$ & $6.0 \pm 0.4$ & 47 \\
\hline & S. typhimurium & 0.72 & 0.89 & $4 \pm 6$ & $0.41 \pm 0.16$ & $6.0 \pm 0.7$ & 4 \\
\hline & TIC & 0.26 & 0.83 & $82 \pm 55$ & $0.46 \pm 0.23$ & $10.8 \pm 0.2$ & 68 \\
\hline & HPC (alongside TIC) & 0.25 & 0.80 & $119 \pm 65$ & $0.53 \pm 0.30$ & $6.4 \pm 0.2$ & 66 \\
\hline \multirow[t]{2}{*}{$20{ }^{\circ} \mathrm{C} /$ high $\mathrm{RH}$} & Enterococcus spp. & 0.14 & 0.99 & $123 \pm 10$ & $1.5 \pm 0.1$ & $5.9 \pm 0.1$ & 13 \\
\hline & S. typhimurium & 0.38 & 0.97 & $32 \pm 12$ & $1.1 \pm 0.3$ & $5.8 \pm 0.3$ & 5 \\
\hline \multirow[t]{3}{*}{$5-6{ }^{\circ} \mathrm{C} /$ low $\mathrm{RH}$} & HPC (Eawag) & $0.17^{e}$ & 0.98 & $15 \pm 8$ & $0.41 \pm 0.09$ & $7.5 \pm 0.2$ & 18 \\
\hline & Enterococcus spp. & 0.13 & 0.93 & $325 \pm 59$ & $0.63 \pm 0.15$ & $6.1 \pm 0.1$ & 123 \\
\hline & S. typhimurium & 0.35 & 0.85 & $114 \pm 70$ & $0.56 \pm 0.21$ & $6.0 \pm 0.2$ & 57 \\
\hline \multirow[t]{8}{*}{$5-6{ }^{\circ} \mathrm{C} /$ High RH } & HPC (Eawag) & 0.22 & 0.94 & $144 \pm 31$ & $1.1 \pm 0.3$ & $7.4 \pm 0.2$ & 22 \\
\hline & HPC (eThekwini) & 0.11 & 0.90 & $265 \pm 33$ & $2.3 \pm 1.1$ & $6.4 \pm 0.1$ & 20 \\
\hline & & 0.29 & 0.95 & $23 \pm 16$ & $0.50 \pm 0.15$ & $7.9 \pm 0.3$ & 15 \\
\hline & & 0.36 & 0.93 & $36 \pm 26$ & $0.62 \pm 0.25$ & $7.9 \pm 0.3$ & 14 \\
\hline & Enterococcus spp. & 0.08 & 0.99 & $275 \pm 11$ & $1.7 \pm 0.1$ & $5.92 \pm 0.03$ & 25 \\
\hline & S. typhimurium & 0.20 & 0.98 & $170 \pm 21$ & $1.3 \pm 0.1$ & $5.9 \pm 0.1$ & 21 \\
\hline & TIC & 0.07 & 0.54 & $784 \pm 1096$ & $1.2 \pm 1.2$ & $10.62 \pm 0.04$ & 101 \\
\hline & HPC (alongside TIC) & 0.07 & 0.85 & $217 \pm 17$ & $6.3 \pm 3.7$ & $6.34 \pm 0.03$ & 11 \\
\hline
\end{tabular}

${ }^{a}$ RMSE, Root mean sum of squared errors. ${ }^{b} \delta$, time for first decimal reduction. ${ }^{c} p$, Weibull model shape parameter. ${ }^{d} t_{4 \mathrm{D}}$, time for 4 -decimal (99.99\%) reduction projected from model fit. ${ }^{e}$ Five observations used for model fit. A minimum of at least six observations is preferable for Weibull model parametrization.

(low humidity $/ 35^{\circ} \mathrm{C}$ and high humidity $/ 5^{\circ} \mathrm{C}$ ). Heterotrophic bacteria from different sources exhibited variable susceptibility to inactivation (Figure 2, Table 1 and Table S2). At a given relative humidity and within the same urine batch, inactivation was generally more efficient at higher temperatures. Conversely, the effect of relative humidity on inactivation at a given temperature was less clear. At the low temperature condition, increased relative humidity increased the time for 1-log reduction, but this effect was not observed during higher temperature storage. Elsewhere it has been observed that heterotrophs are more sensitive to heating in wet soil than dry soils. $^{25}$ In all cases, HPC bacteria were not reduced below the detection limit over the time period monitored.

Decrey et al. ${ }^{16}$ found that the reduced moisture content of struvite during drying was the primary cause of inactivation of bacteriophage and helminth ova. Reduction in moisture content is also known to inactivate bacteria, such as during the drying of wastewater sludge. ${ }^{26}$ Inactivation may stem from changes in porewater solution conditions and from cellular changes during desiccation. In the porewater, parameters of interest are the $\mathrm{pH}$, ionic strength and the concentration of $\mathrm{NH}_{3}$, which is a known biocide. Decrey et al. ${ }^{16}$ performed a simulation of these parameters as a function of moisture reduction in struvite (at 35 ${ }^{\circ} \mathrm{C}$, Low $\mathrm{RH}$ ). The $\mathrm{NH}_{3}$ concentration declines rapidly with moisture, and the $\mathrm{pH}$ approaches neutral. Therefore, after about $20 \%$ moisture loss, these two parameters are not expected to contribute to inactivation. The ionic strength does increase at low moisture (after about $80 \%$ moisture loss). Such low moisture conditions were achieved rapidly in most struvite drying tests (Figure S4); thus ionic strength may promote inactivation in our samples.

Changes in conditions at the cellular level during desiccation, including increased ionic strength, changes in cellular compartment volumes, increased viscosity, the crowding of macromolecules, damage to external layers, and changes in physiological processes, contribute to inactivation. ${ }^{27}$ Reduced stability of DNA under such altered conditions is also known as a major contributor to cell death during dehydration. ${ }^{28}$ In our data, a linear relationship was observed independently of the drying condition between heterotrophic bacteria inactivation 
Table 2. Linear Regression Results for Inactivation $\left(\log _{10} \mathrm{C} / \mathrm{C}_{0}\right.$ or $\left.C / C_{0}\right)$ versus Effective Moisture Content $\left(\log _{10} \theta_{\mathrm{g}}\right.$ or $\left.\theta_{\mathrm{g}}\right)$

\begin{tabular}{|c|c|c|c|c|c|c|c|}
\hline \multirow[b]{2}{*}{ bacteria group } & \multirow[b]{2}{*}{ drying condition } & \multicolumn{3}{|c|}{$\log _{10} C / C_{0}$ vs $\log _{10} \theta_{\mathrm{g}}^{a}$} & \multicolumn{3}{|c|}{$C / C_{0}$ vs $\theta_{\mathrm{g}}{ }^{b}$} \\
\hline & & $R^{2}$ & slope $\pm \mathrm{SE}^{c}$ & intercept $\pm S E$ & $R^{2}$ & slope \pm SE & intercept $\pm \mathrm{SE}$ \\
\hline heterotrophic bacteria & field drying in cloth bag filters & 0.28 & $0.60 \pm 0.14$ & $-0.39 \pm 0.11$ & 0.11 & $0.82 \pm 0.33$ & $0.22 \pm 0.30$ \\
\hline heterotrophic bacteria & field drying on nylon filters & 0.68 & $0.71 \pm 0.07$ & $-0.30 \pm 0.10$ & 0.11 & $0.60 \pm 0.23$ & $0.33 \pm 0.26$ \\
\hline heterotrophic bacteria & controlled drying on nylon filters & 0.50 & $0.65 \pm 0.05$ & $-0.27 \pm 0.08$ & 0.34 & $0.48 \pm 0.05$ & $0.20 \pm 0.05$ \\
\hline Enterococcus spp. & controlled drying on nylon filters & 0.45 & $0.66 \pm 0.08$ & $-0.14 \pm 0.08$ & 0.77 & $0.73 \pm 0.04$ & $0.12 \pm 0.04$ \\
\hline S. typhimurium & controlled drying on nylon filters & 0.53 & $1.04 \pm 0.11$ & $-0.47 \pm 0.11$ & 0.74 & $0.65 \pm 0.04$ & $-0.003 \pm 0.03$ \\
\hline
\end{tabular}

(a)

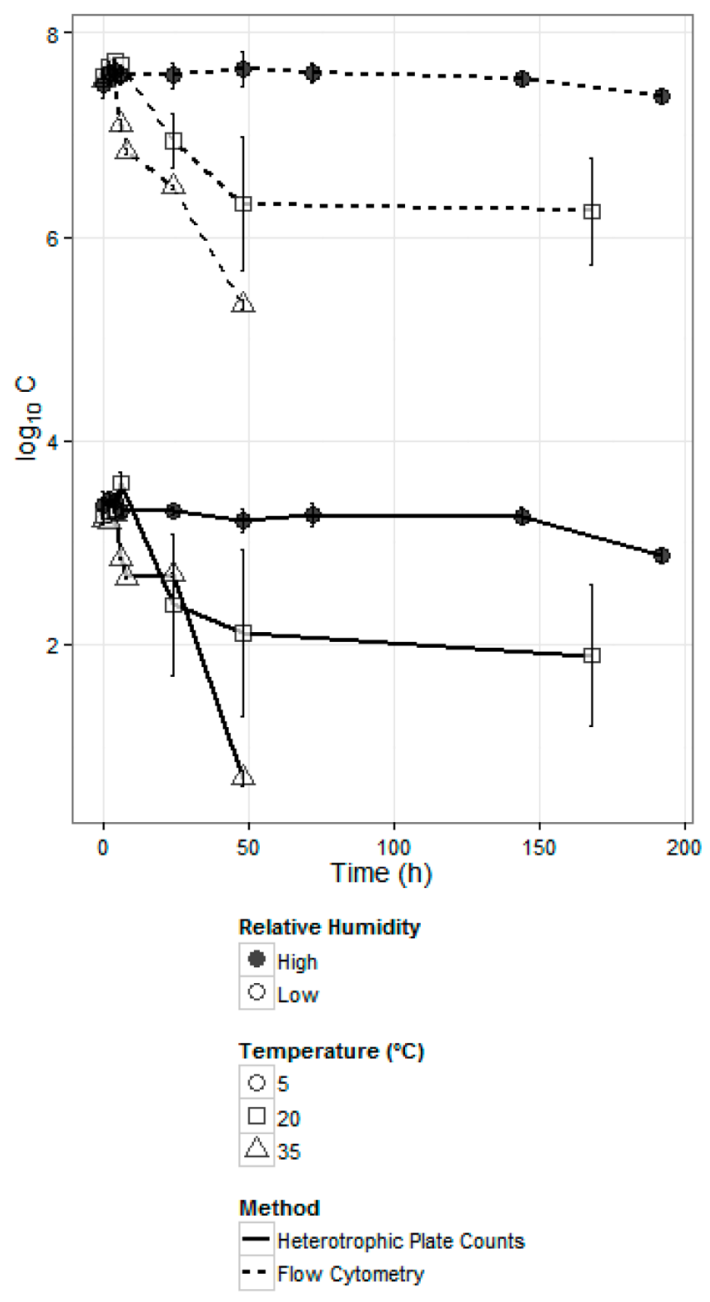

(b)
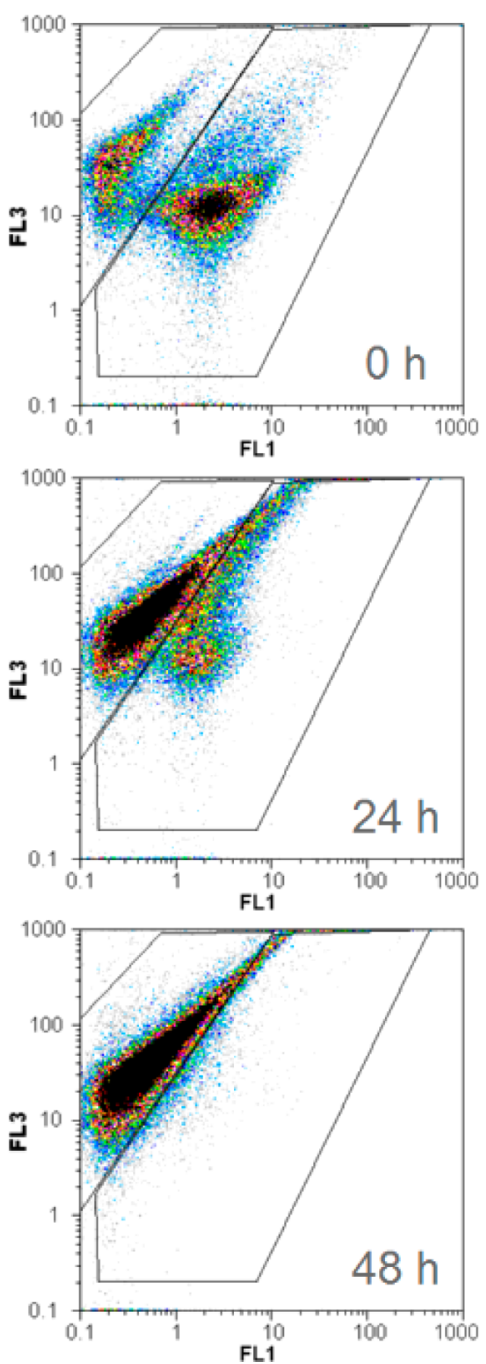

Figure 3. Concentrations $\left(\log _{10} \mathrm{C}\right)$ of in situ heterotrophic bacteria (CFU/g struvite) monitored side-by-side with total intact cells (counts/g struvite) by flow cytometry in struvite dried at different temperature and relative humidity conditions (a). Representative FL1 (green) vs FL3 (red) fluorescence emission dot plots from struvite drying experiments conducted at $35{ }^{\circ} \mathrm{C}$ and low relative humidity ( 40\%) (1000-fold dilution of struvite sample) demonstrate the transition of cells from intact (right side gated region) to membrane compromised (left side gated region) with time (b). Each dot on the plot represents a detection event (256 channels per axis), and the color gradient represents the $z$-axis with a single event shown in blue and greater than 16 events shown as black.

$\left(\log _{10} C / C_{\mathrm{o}}\right)$ and the effective moisture content $\left(\log _{10} \theta_{\mathrm{g}}\right.$, Figure $2 \mathrm{~b}$ ). The correlations of residual moisture content with bacteria inactivation, however, were often weak (Table 2). Therefore, the reduction in sample moisture content could be used as a rudimentary proxy for estimating the log reduction of bacteria during struvite drying over a range of drying temperatures and relative humidity. However, concentrations of in situ heterotrophic bacteria in struvite may stabilize during drying, as indicated by the tailing inactivation curves at low relative humidity (Figure 2a), thereby limiting the utility of this proxy at low water contents.

Inactivation of Human Pathogen Surrogate Bacteria during Controlled Drying of Struvite. While HPC have been used historically to provide an indication of the overall microbial status of an environment, HPC bacteria include mostly nonpathogenic organisms. Evaluation of fecal indicator bacteria and Salmonella were conducted to assess the agreement of the findings using HPC with human health 
relevant bacteria. The inactivation of inoculated Enterococcus spp. and S. typhimurium was monitored during struvite drying under controlled temperature and relative humidity for comparison to results for heterotrophic bacteria (Figure 2a). In a study of thermal resistance to eight nonspore forming bacteria in mild heating conditions, Enterococcus faecalis and Salmonella typhimurium represented extreme responses (most resistant and least resistant, respectively). ${ }^{29}$ In the present study, both bacteria were partly inactivated during struvite drying, and the inactivation typically increased with increasing drying temperature (from 5 to $35{ }^{\circ} \mathrm{C}$ ) for a given relative humidity, with a more pronounced increase with temperature for S. typhimurium relative to Enterococcus spp.

As observed for heterotrophic bacteria, the varied behaviors observed for Enterococcus spp. and S. typhimurium dried under different conditions do approximate into a linear relationship when inactivation $\left(\log _{10} C / C_{\mathrm{o}}\right)$ is plotted against the effective struvite moisture content (Figure $2 \mathrm{~b}$ ). Therefore, the moisture content of the struvite cake can be a useful parameter to evaluate the extent of microbial inactivation. Gram positive Enterococcus spp. responded to drying at similar rates to heterotrophic bacteria, while Gram-negative S. typhimurium was inactivated more efficiently than both, resulting in a steeper inactivation vs moisture content relationship (Table 2). This suggests that results from HPC provide a good indicator of treatment processes efficiency for Enterococcus spp. and a conservative indicator for S. typhimurium.

Inactivation of the Total Bacterial Population. FC measurements of in situ total bacterial population were taken alongside HPC measurements for a series of controlled struvite drying conditions (Figure 3) to evaluate the ability of the cultivation-dependent method to reflect total bacteria behavior during struvite drying and to explore the mechanism of inactivation. The ease of use and comprehensive detection capabilities of FC render this method favorable for rapid and extensive data collection.

Similar to HPC bacteria, total cell counts and total intact cells from FC analysis were consistently detected above the detection limit throughout the drying experiments. Total intact cells declined over time during drying (Figure 3), indicating loss of the cytoplasmic membrane integrity of detected cells, while total cell counts remained stable throughout the experiments (Figure S5). A strong correlation between HPC and total intact cells in the same samples was observed (Figure S6) independently of drying condition, suggesting that HPC does serve as a useful proxy for following the progression of overall bacterial inactivation, as characterized by membrane integrity, during struvite drying. The strong correlation observed may be a result of a relatively homogeneous starting bacterial population in the stored urine. ${ }^{23}$ Storage of urine prior to use for production of struvite is known to rapidly inactivate some bacteria, while those remaining must be tolerant of the high ammonia levels and elevated $\mathrm{pH}$ typical of stored urine (2.6-3.3 g/L N-NH${ }_{4}^{+}$and 8.5-9.4, respectively). ${ }^{30}$

Despite the benefits of using FC, our cultivation-independent assessment of viability just mirrored the inactivation trends as captured via HPC under a range of conditions. The Grampositive bacteria Enterococcus spp. also followed a progression similar to heterotrophic bacteria during drying. Therefore, our results suggest that HPC continue to be a useful method for assessing struvite end-product quality, especially in lowresource field settings.
Nonlinear Inactivation Kinetics and Bacterial Persistence during Drying at Low Relative Humidity. At low relative humidity, heterotrophic bacteria in urine from different sources as well as Enterococcus spp. and S. typhimurium tended to be inactivated rapidly initially but stabilized with time. Such tailing of the inactivation curve was typically not observed in the higher relative humidity drying condition in the time frame monitored, though inactivation was generally slower at higher relative humidity. The tailing feature observed at lower relative humidity implies the need for a nonlinear inactivation model, such as the Weibull model, to predict the time to achieve desired inactivation (e.g., the time for 4-log reduction). Weibull model parameters determined for all test organisms are listed in Table 1, and corresponding first-order inactivation rate constants (from the application a Weibull model with fixed $p$ = 1) for each are listed in Table S2.

For heterotrophic bacteria, the time for first log reduction $(\delta)$ in struvite was 1 day or less when dried at low humidity and $35^{\circ} \mathrm{C}$, but $\delta$ ranged from 1 to 11 days when struvite was dried at high humidity and low temperature. Conversely, extrapolation of the Weibull model predicted a longer time on average for 4-log reduction at low humidity/high temperature compared to the high humidity/low temperature conditions. This is attributable to the occurrence of tailing $(p<1)$ at low humidity and shouldering $(p>1)$ at high humidity. Notably, applying a simple first-order inactivation model would either under- (low humidity) or overpredict (high relative humidity) the required 4-log inactivation times, highlighting the need for a more complex inactivation model. Similar results were observed for both Enterococcus spp. and S. typhimurium in which the average $p$ was greater than one when struvite was dried under high relative humidity but less than one when dried at low relative humidity. Consistent with the previous discussion, this indicates that it is beneficial to dry struvite at higher temperature but not reduced relative humidity. Further, the relatively consistent change in curve shape with relative humidity may be indicative of a shift in the primary inactivation mechanism under different drying conditions.

Nonlinear microbial inactivation curves are commonly observed during mild heat treatment, though the causes of this behavior, whether physical, chemical or biochemical, are still debated. ${ }^{31}$ For example, the appearance of a shoulder, or a lag-time before inactivation, has been attributed to an accumulation of sublethal injury prior to inactivation, repair of cellular damage and aggregation of cells. ${ }^{32,33}$ Tailing of heatdriven inactivation curves has been proposed as a consequence of the decrease in the probability of a collision between a water molecule that carries sufficient thermal energy to be lethal and a microbial particle as microorganisms are inactivated. ${ }^{34}$ In a study of bacterial inactivation in soils, evaporation of moisture during heating in low relative humidity cooled the wetted inoculum relative to external temperatures and reduced inactivation. ${ }^{35}$ This could explain tailing observed in the present study at low relative humidity. An alternative explanation for tailing is the presence of a resistant subpopulation. Removing water from cells causes damage to cellular components, leading to death in most organisms. For example, DNA double strand breaks are high under desiccation conditions in Escherichia coli. ${ }^{36,37}$ However, organisms that experience frequent droughts, such as in soils, are known to exhibit mechanisms for protection against desiccation or to repair ensuing damage. ${ }^{27}$ Desiccation resistant microorganisms such as the pathogen Staphylococcus aureus tend to be Gram- 

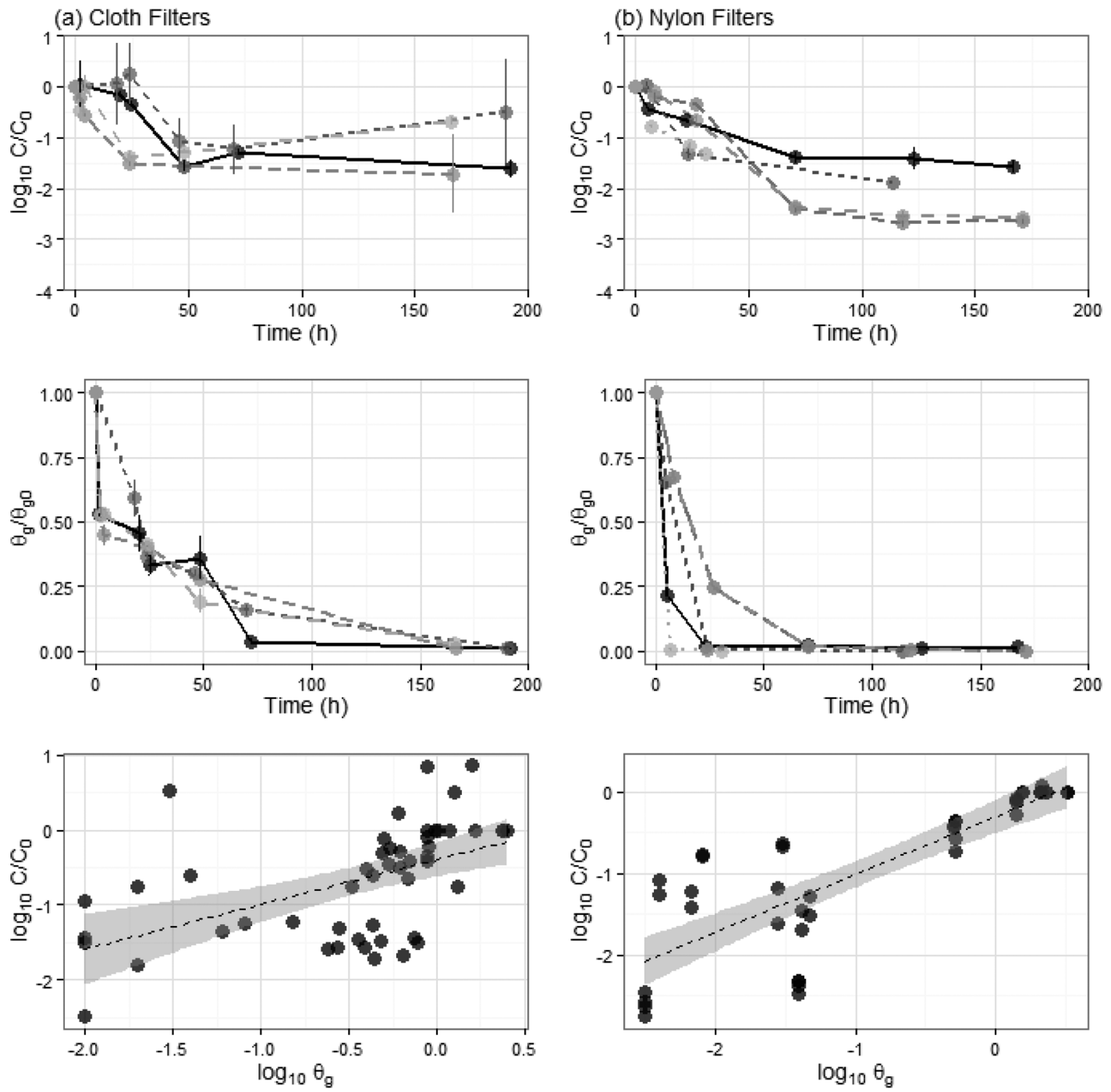

Figure 4. Replicate struvite cakes produced from cloth filters (a) or nylon filters (b) and dried at ambient conditions, as outlined in Table S3.

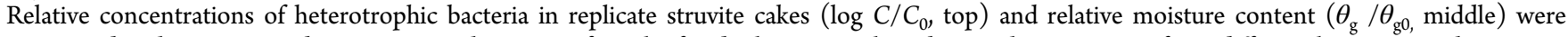
monitored with time. Error bars represent the range of results for duplicate samples taken at the same time from different locations in the struvite cake. Relative heterotrophic bacteria concentrations from individual samples are shown separately with their corresponding moisture content to evaluate the relationship between these variables (bottom).

positive and small. ${ }^{27,28,38}$ However, Gram-negative Salmonella has also been shown to survive in low moisture content conditions $^{26}$ due at least in part to the water-retaining capacity of expressed lipopolysaccharides. ${ }^{39}$ This is consistent with observed tailing of the S. typhimurium survivor curves at low relative humidity in the present study.

Dynamic processes during struvite drying, such as rates of heating and dehydration or changes in struvite porewater chemical composition with time, may also influence inactivation kinetics. Struvite porewater ionic strength increases rapidly in laboratory-produced struvite when the moisture content is reduced by more than approximately $80 \%{ }^{16}$ Drying struvite at higher relative humidity could reduce the drying rate and affect microbial inactivation. For example, survival of Salmonella may be greater when dehydration is gradual. ${ }^{39}$ Poirier et al. ${ }^{40}$ showed that decreasing the rate of change in water potential increased the viability of several bacterial cells likely due to associated reductions in water flow rates across cell membranes. ${ }^{40}$ Down- or upregulation of biological processes, such as metabolic rates, DNA repair capabilities, or systems to scavenge reactive oxygen species, during slow dehydration can influence bacterial survival. ${ }^{37,41}$ However, high relative humidity can also lead to more efficient inactivation of dehydration tolerant bacteria, as shown for Deinococcus radiodurans cells. ${ }^{36,37}$

With regards to struvite, initial retention of moisture during thermal treatment may aid in achieving inactivation objectives. Because struvite cannot be dried at high temperatures (approximately $>55{ }^{\circ} \mathrm{C}$ ) without some reduction of fertilizer quality due to loss of ammonia, ${ }^{42}$ low levels of moisture are likely present in the final product in any case. For long-term storage of sludge, maintaining a moisture content of $15 \%$ was recommended to encourage inactivation of bacteria while also preventing regrowth of enteric bacteria. ${ }^{26}$ Lower moisture contents $(<10 \%)$ protected bacteria from inactivation while higher moisture content promoted regrowth. ${ }^{26}$ The precise optimum moisture content to promote inactivation during long-term storage of struvite was not evaluated in the present study. Reduced moisture of struvite is important nevertheless for viral and helminth inactivation. ${ }^{16}$ 
Persistence of Heterotrophic Bacteria in Struvite Dried under Field Conditions. Struvite produced in the field is exposed to dynamic, rather than constant drying conditions. It is known that bacterial inactivation during isothermal drying does not necessarily predict behavior under fluctuating temperature and relative humidity. ${ }^{43,44}$

To evaluate the effect of dynamic environmental conditions (Figure S7-Figure S10) on the efficiency of inactivation of heterotrophic bacteria relative to controlled drying conditions, we air-dried struvite produced from both $1 \mathrm{~L}$ on nylon filters and $320 \mathrm{~L}$ batches captured in cloth bags (Table S3) in the field. The mass of struvite on nylon filters ( 1 to $4 \mathrm{~g}$ initial ww) was much lower, and the thickness of the cakes was more homogeneous (Figure S11), compared to struvite mass captured in cloth filter bags $(600-1200 \mathrm{~g}$ initial ww). The average temperature for the period in which struvite was dried outside on nylon filters was $21 \pm 2(\mathrm{SD}){ }^{\circ} \mathrm{C}$, ranging from 17 to $34{ }^{\circ} \mathrm{C}$. Over this time, the relative humidity averaged $72 \pm$ $11 \%$ and ranged from 44 to $91 \%$. The average measured temperature for struvite dried in cloth filter bags was $16 \pm 6$ (SD) ${ }^{\circ} \mathrm{C}$ and ranged from 5 to $43{ }^{\circ} \mathrm{C}$. The plastic cover used to protect the cloth filters from rain may have increased the temperature measured nearby the struvite bags relative to ambient daily temperatures, which reach a maximum of $35^{\circ} \mathrm{C}$ in Durban during the drying period. ${ }^{45}$ Average relative humidity was $64 \pm 22 \%$ over the drying period for cloth filter bags and ranged from 12 to $98 \%$.

Despite diurnal fluctuations in temperature and relative humidity, the moisture content of struvite cakes decreased rapidly (Figure 4), and the decline was within the range of the drying rates from controlled drying tests (Figure S4). As expected from the differences in struvite mass captured by each filter, the moisture content declined more rapidly for struvite dried on nylon filters than for struvite in cloth bags, and remained low in both following the declines. However, HPC concentrations declined slowly, and slopes of the log-linear inactivation curves were frequently not significantly different from zero, especially for struvite dried in larger batches in the cloth filter bags (Table S3). Similarly to controlled tests, heterotrophic bacteria remained detectable throughout the experiments. The time for first $\log$ reduction $(\delta)$ of heterotrophs in the field was generally greater than that determined in the laboratory. From the application of the Weibull model (fixed $p=0.38$ ), $\delta$ ranged from 9 to 48 days in struvite filtered and dried on nylon filters and from 26 to 201 days for heterotrophs in struvite captured and dried in cloth filter bags (Table S4). This is in contrast to $\delta$ values of 11 days or less for HPC bacteria inactivation in struvite dried under any controlled condition in the laboratory (Table 1).

Notwithstanding some differences in the inactivation rates between the laboratory and the field, the relation between inactivation and moisture content was rather consistent. For comparison to inactivation in isothermal conditions, a linear regression was also performed to assess the relation between inactivation $\left(\log _{10} C / C_{0}\right)$ and moisture content $\left(\log _{10} \theta_{\mathrm{g}}\right)$ in the field (Figure 4). While the coefficients of determination are low, as may be expected for environmental conditions, the slopes of the $\log$ inactivation vs $\log$ moisture plots are consistent for HPC bacteria in struvite dried in the laboratory or field conditions and similar to that of both HPC bacteria and Enterococcus spp. in struvite dried under isothermal conditions (Table 2). Therefore, while average drying temperature or relative humidity in field conditions do not reflect inactivation observed during similar isothermal controls, the moisture content of struvite samples served as a rough indicator of bacteria inactivation in the fertilizer.

Recommendations for Enhanced Struvite Production. Struvite moisture content may be a more useful parameter than elapsed time to evaluate bacterial inactivation during struvite production because linear relationships were observed between inactivation and moisture content irrespective of drying condition. The moisture content relationship for HPC was similar in struvite dried under isothermal conditions in the laboratory and under dynamic environmental conditions in the field. However, greater variability in inactivation was observed in struvite produced from pilot-scale struvite reactors under fluctuating temperature and relative humidity drying conditions. Further, the relationship between inactivation and moisture content did not reflect the change in inactivation mechanism observed between high and low relative humidity drying conditions in the laboratory. Tailing of the survivor curves occurred at low relative humidity despite attainment of low moisture content, and low levels of heterotrophic bacteria persisted in all drying conditions. The relationships between inactivation and moisture content also differed by bacterial type. Consequently, the moisture content relationship may fail at low moisture contents and under dynamic drying conditions.

Increased homogeneity of struvite cakes produced in the field could reduce variability in observed inactivation. This could be achieved, for example, through the application of flat cotton filters in an automated pilot-scale struvite reactor developed in eThekwini. ${ }^{46}$ Such a reactor yields a thinner struvite cake relative to the cloth filter bags and likely more consistent moisture across the retained struvite during treatment. Conversely, increased homogeneity of the struvite cake may affect the accumulation of bacteria from urine into struvite via modified straining of bacteria in the struvite cake during its formation.

While the utilization of nonlethal temperatures for struvite drying provided a treatment benefit, drying at elevated temperature was beneficial in terms of bacterial inactivation. It may be possible to treat struvite at elevated temperatures without reducing the struvite quality. Mass loss of struvite heated to $55{ }^{\circ} \mathrm{C}$ may be minimal, for example, if the rate and time of heating is controlled. ${ }^{42,47}$ This increased temperature is likely to have significant treatment benefits. Heating to 55-60 ${ }^{\circ} \mathrm{C}$, for example, was recommended to inactivate eight nonspore forming bacterial pathogens in water. ${ }^{29}$ For thermal treatment of sewage sludge, the U.S. EPA requires a minimum temperature of $50{ }^{\circ} \mathrm{C}$ as time-temperature relationships at lower temperatures are uncertain; a minimum of $55^{\circ} \mathrm{C}$ must be maintained for three consecutive days for within-vessel composting of sewage sludge. ${ }^{48}$ Additionally, given the observation of sustained inactivation at higher relative humidity, it may be beneficial to treat struvite with elevated moisture levels prior to desiccation. Low temperature, short duration steaming (e.g., at $50{ }^{\circ} \mathrm{C}$ for $3 \mathrm{~min}$ ) has been recommended as a nonchemical alternative for soil pasteurization that also requires less energy than a typical procedure of 30 min treatment at 70 ${ }^{\circ} \mathrm{C} .{ }^{49}$ Elevated temperature treatment with moisture retention can be achieved with little additional cost: temperatures of 45$60{ }^{\circ} \mathrm{C}$ are common in soil solarization in Mediterranean regions. $^{35,49}$

Because some bacteria are more susceptible to dehydration, and desiccation is important for inactivation of viruses and helminths in struvite, reducing the moisture content of the solid 
following any wet treatment remains important. As observed in biosolids, regrowth of pathogens may occur when moisture content is high (or when solids are rewetted) and other bacteria that inhibit regrowth due to competition are absent. ${ }^{50}$ Proper storage of struvite following drying should be therefore conducted to prevent later fluctuations in moisture content.

\section{ASSOCIATED CONTENT}

\section{S Supporting Information}

The Supporting Information is available free of charge on the ACS Publications website at DOI: 10.1021/acs.est.6b03555.

Contains method details, struvite moisture content evolution, chemical parameters measured in urine, model results, climactic data for drying experiments, and experimental setup photos (PDF)

\section{AUTHOR INFORMATION}

\section{Corresponding Author}

*Phone: +41 21693 0891; fax: +41 2169347 40; e-mail: tamar.kohn@epfl.ch.

\section{ORCID ${ }^{\circ}$}

Tamar Kohn: 0000-0003-0395-6561

\section{Author Contributions}

"S.S. and M.S. contributed equally.

\section{Notes}

The authors declare no competing financial interest.

\section{ACKNOWLEDGMENTS}

This material is based upon work supported by the National Science Foundation under Grant No. 1159225. The study was undertaken in the framework of the Valorisation of Urine Nutrients in Africa (VUNA) project funded by the Bill \& Melinda Gates Foundation (www.vuna.ch, Grant No. OPP1011603). Funding was also provided by the Swiss National Science Foundation (grant no. 200021_146829/1). We thank Teddy Gounden and the EWS staff, Franziska Bosshard, Bastian Etter, Max Grau, Sara Rhoton, Nicola Rodda, and Bruce Ndlovu for laboratory and field site access as well as assistance with struvite production and sample analysis.

\section{REFERENCES}

(1) Doyle, J. D.; Parsons, S. A. Struvite Formation, Control and Recovery. Water Res. 2002, 36, 3925-3940.

(2) Le Corre, K. S.; Valsami-Jones, E.; Hobbs, P.; Parsons, S. A. Phosphorus Recovery from Wastewater by Struvite Crystallization: A Review. Crit. Rev. Environ. Sci. Technol. 2009, 39, 433-477.

(3) Elser, J.; Bennett, E. Phosphorus Cycle: A Broken Biogeochemical Cycle. Nature 2011, 478, 29-31.

(4) Bonvin, C.; Etter, B.; Udert, K. M.; Frossard, E.; Nanzer, S.; Tamburini, F.; Oberson, A. Plant Uptake of Phosphorus and Nitrogen Recycled from Synthetic Source-Separated Urine. Ambio 2015, 44, 217-227.

(5) Tilley, E.; Gantenbein, B.; Khadka, R.; Zurbrügg, C.; Udert, K. M. Social and Economic Feasibility of Struvite Recovery from Urine at the Community Level in Nepal. In International Conference on Nutrient Recovery from Wastewater Streams; IWA Publishing: Vancouver, British Columbia, 2009; pp 169-178.

(6) Etter, B.; Tilley, E.; Khadka, R.; Udert, K. M. Low-Cost Struvite Production Using Source-Separated Urine in Nepal. Water Res. 2011, $45,852-862$.

(7) Antonini, S.; Paris, S.; Eichert, T.; Clemens, J. Nitrogen and Phosphorus Recovery from Human Urine by Struvite Precipitation and Air Stripping in Vietnam. Clean: Soil, Air, Water 2011, 39, 10991104.

(8) Grau, M. G. P.; Rhoton, S. L.; Brouckaert, C. J.; Buckley, C. A. Evaluation of an Automated Struvite Reactor to Recover Phosphorus from Source-Separated Urine Collected at Urine Diversion Toilets in Ethekwini. Water SA 2015, 41, 383-389.

(9) Rhoton, S.; Grau, M.; Brouckaert, C. J.; Gounden, G.; Buckley, C. A. Field Operation of a Simple Struvite Reactor to Produce Phosphorus Fertiliser from Source-Separated Urine in eThekwini. In WISA Biennal Conference May 25-28, 2014; Mbombela, Mpumalanga, South Africa, 2014; pp 1-5.

(10) Mihelcic, J. R.; Fry, L. M.; Shaw, R. Global Potential of Phosphorus Recovery from Human Urine and Feces. Chemosphere 2011, 84, 832-839.

(11) World Health Organization. Guidelines for the Safe Use of Wastewater, Excreta and Greywater, Vol. 4: Excreta and Greywater Use in Agriculture; WHO Press: Geneva, Switzerland, 2006; Vol. 4.

(12) Larsen, T. A.; Udert, K. M.; Lienert, J. Source Separation and Decentralization for Wastewater Management; IWA Publishing: London, UK, 2013.

(13) Bischel, H. N.; Özel Duygan, B. D.; Strande, L.; McArdell, C. S.; Udert, K. M.; Kohn, T. Pathogens and Pharmaceuticals in SourceSeparated Urine in eThekwini, South Africa. Water Res. 2015, 85, 5765.

(14) Escher, B. I.; Pronk, W.; Suter, M. J. F.; Maurer, M. Monitoring the Removal Efficiency of Pharmaceuticals and Hormones in Different Treatment Processes of Source-Separated Urine with Bioassays. Environ. Sci. Technol. 2006, 40, 5095-5101.

(15) Ronteltap, M.; Maurer, M.; Gujer, W. The Behaviour of Pharmaceuticals and Heavy Metals during Struvite Precipitation in Urine. Water Res. 2007, 41, 1859-1868.

(16) Decrey, L.; Udert, K. M.; Tilley, E.; Pecson, B. M.; Kohn, T. Fate of the Pathogen Indicators Phage ФX174 and Ascaris Suum Eggs during the Production of Struvite Fertilizer from Source-Separated Urine. Water Res. 2011, 45, 4960-4972.

(17) Berney, M.; Hammes, F.; Bosshard, F.; Weilenmann, H.-U.; Egli, T. Assessment and Interpretation of Bacterial Viability by Using the LIVE/DEAD BacLight Kit in Combination with Flow Cytometry. Appl. Environ. Microbiol. 2007, 73, 3283-90.

(18) Mafart, P.; Couvert, O.; Gaillard, S.; Leguerinel, I. On Calculating Sterility in Thermal Preservation Methods: Application of the Weibull Frequency Distribution Model. Acta Hortic. 2001, 566, $107-114$

(19) Geeraerd, A. H.; Valdramidis, V. P.; Van Impe, J. F. GInaFiT, a Freeware Tool to Assess Non-Log-Linear Microbial Survivor Curves. Int. J. Food Microbiol. 2005, 102, 95-105.

(20) Van Boekel, M. A. J. S. On the Use of the Weibull Model to Describe Thermal Inactivation of Microbial Vegetative Cells. Int. J. Food Microbiol. 2002, 74, 139-159.

(21) Goosse, P. Erste Monitoringergebnisse Im Forum Chriesbach (NoMix Toilet System, First Monitoring Results in Forum Chriesbach, in German). Gas Wasser Abwasser 2009, 7, 567-574.

(22) Vinneras, B.; Nordin, A.; Niwagaba, C.; Nyberg, K. Inactivation of Bacteria and Viruses in Human Urine Depending on Temperature and Dilution Rate. Water Res. 2008, 42, 4067-4074.

(23) Lahr, R. H.; Goetsch, H. E.; Haig, S. J.; Noe-Hays, A.; Love, N. G.; Aga, D. S.; Bott, C. B.; Foxman, B.; Jimenez, J.; Luo, T.; Nace, K.; Ramadugu, K.; Wigginton, K. R. Urine Bacterial Community Convergence through Fertilizer Production: Storage, Pasteurization, and Struvite Precipitation. Environ. Sci. Technol. 2016, 50, 1161911626.

(24) Höglund, C. E.; Stenström, T. A. B. Survival of Cryptosporidium Parvum Oocysts in Source Separated Human Urine. Can. J. Microbiol. 1999, 45, 740-746.

(25) Dunn, P. H.; Barro, S. C.; Poth, M. Soil Moisture Affects Survival of Microorganisms in Heated Chaparral Soil. Soil Biol. Biochem. 1985, 17, 143-148. 
(26) Yeager, J. G.; Wardt, R. L. Effects of Moisture Content on LongTerm Survival and Regrowth of Bacteria in Wastewater Sludge 1981, 41, $1117-1122$.

(27) Potts, M.; Slaughter, S. M.; Hunneke, F.; Garst, J. F.; Helm, F.; Potrs, M.; Helm, R. E. Desiccation Tolerance of Prokaryotes: Application of Principles to Human Cells Desiccation Tolerance of Prokaryotes: To Human Cells ' of Principles Application. Integr. Comp. Biol. 2005, 45, 800-809.

(28) Potts, M. Desiccation Tolerance of Prokaryotes. Microbiol. Rev. 1994, 58, 755-805.

(29) Spinks, A. T.; Dunstan, R. H.; Harrison, T.; Coombes, P.; Kuczera, G. Thermal Inactivation of Water-Borne Pathogenic and Indicator Bacteria at Sub-Boiling Temperatures. Water Res. 2006, 40, $1326-1332$.

(30) Höglund, C.; Vinnerås, B.; Stenström, T. a.; Jönsson, H. Variation of Chemical and Microbial Parameters in Collection and Storage Tanks for Source Separated Human Urine. J. Environ. Sci. Health, Part A: Toxic/Hazard. Subst. Environ. Eng. 2000, 35, 14631475.

(31) Geeraerd, A. H.; Herremans, C. H.; Van Impe, J. F. Structural Model Requirements to Describe Microbial Inactivation during a Mild Heat Treatment. Int. J. Food Microbiol. 2000, 59, 185-209.

(32) Virto, R.; Mañas, P.; Álvarez, I.; Condon, S.; Raso, J. Membrane Damage and Microbial Inactivation by Chlorine in the Absence and Presence of a Chlorine-Demanding Substrate. Appl. Environ. Microbiol. 2005, 71, 5022-5028.

(33) Wesche, A. M.; Gurtler, J. B.; Marks, B. P.; Ryser, E. T. Stress, Sublethal Injury, Resuscitation, and Virulence of Bacterial Foodborne Pathogens. J. Food Prot. 2009, 72, 1121-1138.

(34) Casolari, A. Microbial Death. In Physiological Models in Microbiology; Bazin, M. J.; Prosser, J. I., Eds.; CRC Press, Inc.: Boca Raton, FL, 1988; Vol. II, pp 1-44.

(35) Shlevin, E.; Mahrer, Y.; Katan, J. Effect of Moisture on Thermal Inactivation of Soilborne Pathogens under Structural Solarization. Phytopathology 2004, 94, 132-7.

(36) Yang, Y.; Yokobori, S. I.; Yamagishi, A. Bacterial Survival in Response to Desiccation and High Humidity at above Zero and Subzero Temperatures. Adv. Space Res. 2009, 43, 1285-1290.

(37) Bauermeister, A.; Moeller, R.; Reitz, G.; Sommer, S.; Rettberg, P. Effect of Relative Humidity on Deinococcus Radiodurans' Resistance to Prolonged Desiccation, Heat, Ionizing, Germicidal, and Environmentally Relevant UV Radiation. Microb. Ecol. 2011, 61, 715722.

(38) Potts, M. Desiccation Tolerance: A Simple Process? Trends Microbiol. 2001, 9, 553-559.

(39) Garmiri, P.; Coles, K. E.; Humphrey, T. J.; Cogan, T. a Role of Outer Membrane Lipopolysaccharides in the Protection of Salmonella Enterica Serovar Typhimurium from Desiccation Damage. FEMS Microbiol. Lett. 2008, 281, 155-9.

(40) Poirier, I.; Marechal, P.; Gervais, P. Effects of the Kinetics of Water Potential Variation on Bacteria Viability. J. Appl. Microbiol. 1997, 82, 101-106.

(41) Hoekstra, F. a; Golovina, E. a; Buitink, J. Mechanisms of Plant Desiccation Tolerance. Trends Plant Sci. 2001, 6, 431-438.

(42) Bhuiyan, M. I. H.; Mavinic, D. S.; Koch, F. A. Thermal Decomposition of Struvite and Its Phase Transition. Chemosphere 2008, 70, 1347-1356.

(43) Ongeng, D.; Muyanja, C.; Geeraerd, a. H.; Springael, D.; Ryckeboer, J. Survival of Escherichia Coli O157:H7 and Salmonella Enterica Serovar Typhimurium in Manure and Manure-Amended Soil under Tropical Climatic Conditions in Sub-Saharan Africa. J. Appl. Microbiol. 2011, 110, 1007-1022.

(44) Semenov, A. V.; Van Bruggen, A. H. C.; Van Overbeek, L.; Termorshuizen, A. J.; Semenov, A. M. Influence of Temperature Fluctuations on Escherichia Coli O157:H7 and Salmonella Enterica Serovar Typhimurium in Cow Manure. FEMS Microbiol. Ecol. 2007, 60, 419-428.

(45) Weather Archive - Durban, June 2014 http://weatherarchive.ru/ Temperature/Durban/June-2014/en (accessed October 19, 2016).
(46) Udert, K. M.; Buckley, C. A.; Wächter, M.; McArdell, C. S.; Kohn, T.; Strande, L.; Zöllig, H.; Hug, A.; Oberson, A.; Etter, B. Technologies for the Treatment of Source-Separated Urine in the eThekwini Municipality. Water SA 2015, 41, 212-221.

(47) Frost, R. L.; Weier, M. L.; Erickson, K. L. Thermal Decomposition of Struvite - implications for the Decomposition of Kidney Stones. J. Therm. Anal. Calorim. 2004, 76, 1025-1033.

(48) U.S. Environmental Protection Agency. Environmental Regulations and Technology: Control of Pathogens and Vector Attraction in Sewage Sludge, 1999; p EPA/625/R-92/013.

(49) van Loenen, M. C. A.; Turbett, Y.; Mullins, C. E.; Feilden, N. E. H.; Wilson, M. J.; Leifert, C.; Seel, W. E. Low Temperature-Short Duration Steaming of Soil Kills Soil-Borne Pathogens, Nematode Pests and Weeds. Eur. J. Plant Pathol. 2003, 109, 993-1002.

(50) Zaleski, K. J.; Josephson, K. L.; Gerba, C. P.; Pepper, I. A. N. L. Survival, Growth, and Regrowth of Enteric Indicator and Pathogenic Bacteria in Biosolids, Compost. Soil, and Land Applied Biosolids 2005, 2, 49-63. 